American Journal of Animal and Veterinary Sciences 5 (3): 168-174, 2010

ISSN 1557-4555

(C) 2010 Science Publications

\title{
Effect of Dietary Carbadox on Apparent Ileal Digestibility of Amino Acids in Weanling Pigs
}

\author{
${ }^{1}$ L.L. Stewart, ${ }^{1}$ B.G. Kim, ${ }^{2}$ B.R. Gramm, ${ }^{2}$ R.D. Nimmo and ${ }^{1}$ H.H. Stein \\ ${ }^{1}$ Department of Animal Sciences, University of Illinois, \\ Urbana, IL 61801, USA \\ ${ }^{2}$ Phibro Animal Health, Ridgefield Park, NJ 07660, USA
}

\begin{abstract}
Problem statement: The objective of this experiment was to determine the effects of carbadox on Apparent Ileal Digestibility (AID) of Amino Acid (AA) by nursery pigs. Approach: Fifteen weanling barrows (initial BW: $9.6 \mathrm{~kg}$ ) were surgically fitted with a T-cannula in the distal ileum. Animals were randomly allocated to three dietary treatments with five pigs per treatment during a 6period experiment. Dietary treatments included: (1) a basal diet (BD) containing mainly corn and soybean meal, (2) BD + $27.5 \mathrm{mg} \mathrm{kg}^{-1}$ of carbadox and (3) BD + $55.0 \mathrm{mg} \mathrm{kg}^{-1}$ of carbadox. Treatment diets were provided during period 2-4; the BD was fed to all pigs during period 1, 5 and 6 . Ileal samples were collected on d 6 and 7 of each period. Results: In pigs fed only the BD throughout the experiment, the AID of CP and many AA was greater during period 2-4 than during period $1(\mathrm{p}<0.05)$. This showed that the AID of CP and AA increased during the first few wk of the experiment. This analysis showed that pigs fed the diet containing $55.0 \mathrm{mg} \mathrm{kg}^{-1}$ of carbadox had greater increases $(\mathrm{p}<0.05)$ in the AID of CP and most AA from period 1 to period 2-4 than pigs that were fed the diet containing no carbadox. The AID for some AA was less during period 5 and 6 compared with period 2-4 for pigs fed diets supplemented with 27.5 or $55.0 \mathrm{mg} \mathrm{kg}^{-1}$ of carbadox $(\mathrm{p}<0.05)$. This observation suggests that there is no carryover effect of carbadox on AA digestibility. Conclusion: Inclusion of carbadox at $55.0 \mathrm{mg} \mathrm{kg}^{-1}$ in diets fed to weanling pigs increased the AID of AA, but carryover effects of dietary carbadox were not observed.
\end{abstract}

Key words: Amino acids, antimicrobial agent, ileal digestibility, swine

\section{INTRODUCTION}

Antimicrobial growth enhancers have been widely used in swine feeding during the last 50 years. Growth promoting responses have been documented for a variety of antimicrobial agents including carbadox (Thrasher et al., 1969; Yen et al., 1976; 1985). The growth promoting effects of antimicrobial agents are often associated with an improved feed efficiency, but the mechanisms responsible for these improvements have not been fully understood.

Antimicrobial agents have been suggested to reduce the concentration of pathogens in the digestive tract of pigs, which will reduce the production of amines and degradation of essential nutrients and thus allow more retention time for digestion and absorption (Cromwell, 2000). Dietary carbadox may reduce the thickness of the intestinal wall, which will enhance absorption of nutrients (Yen et al., 1985). Improvements of $\mathrm{CP}$ digestibility and retention rate by supplemental carbadox have been reported (Yen et al., 1976) and a Lys sparing effect of carbadox has also been suggested (Yen and Veum, 1982).

However, the effects of dietary carbadox on ileal Amino Acid (AA) digestibility have been rarely studied (Partanen et al., 2001). Therefore, the objectives of the present experiment were to determine effects of dietary carbadox on the Apparent Ileal Digestibility (AID) of AA in nursery pigs and to determine if effects of carbadox on AID of AA can be observed after carbadox is removed from the diet.

\section{MATERIALS AND METHODS}

An experiment was conducted in an environmentally controlled room at the University of Illinois. The Institutional Animal Care and Use Committee at the University of Illinois reviewed and approved the protocol for the experiment.

Corresponding Author: Beob G. Kim, Department of Animal Science and Environment, Konkuk University, Seoul 143-701, Korea 
Animals and housing: Fifteen weanling barrows originating from the matings of Line 337 boars to $\mathrm{C} 22$ females (Pig Improvement Company, Hendersonville, TN) were used in this experiment. Animals with an average body weight of $9.6 \mathrm{~kg}(\mathrm{SD}=0.89)$ were surgically fitted with a T-cannula in the distal ileum according to procedures adapted from Stein et al. (1998). Following surgery, pigs were housed individually in metabolism crates. Each crate was equipped with a stainless steel feeder and a nipple waterer. Animals were allowed a 7 day recuperation period following the surgery and were allowed ad libitum access to feed and water throughout the experiment.

Diets, experimental design and sample collection: A basal diet was formulated on the basis of corn and soybean meal (Table 1 and 2). Two additional diets that were identical to the basal diet with the exception that 27.5 or $55.0 \mathrm{mg} \mathrm{kg}^{-1}$ of carbadox was included in these diets were also formulated. A carbadox premix (Mecadox, Phibro Animal Health, Ridgefield Park, NJ) was added to the diets at the expense of cornstarch to achieve the desired levels of carbadox. Chromic oxide was included in all diets as an indigestible marker and vitamins and minerals were included in the diets to meet or exceed current requirement estimates (NRC, 1998).

Animals were randomly assigned to three treatment groups with five pigs per group in a completely randomized design. All pigs were fed the basal diet during the initial 7 day period. Pigs were then fed treatment diets during the next three 7 day periods and all pigs received the basal diet during the final two 7 day periods. Ileal digesta were collected for $8 \mathrm{~h}$ on the 6th and 7th day of each period as described by Stein et al. (1998). Briefly, the cap was removed from the cannula and a $225 \mathrm{~mL}$ plastic bag was attached to the cannula barrel, which allowed digesta to flow into the bag. Bags were removed whenever they were filled with digesta, or at least once every $30 \mathrm{~min}$. All collected samples were stored at $-20^{\circ} \mathrm{C}$ to prevent bacterial degradation of the AA in the digesta.

Chemical analysis: At the conclusion of the experiment, the frozen ileal samples were allowed to thaw at room temperature, mixed within animal and collection period and sub-samples were collected for chemical assay. A sample of each diet was collected as well. Ileal samples were lyophilized and finely ground prior to chemical analysis. All samples were analyzed for DM by drying in an oven at $135^{\circ} \mathrm{C}$ for $2 \mathrm{~h}$ and for $\mathrm{CP}$ using a Rapid N Cube (Elementar Americas Inc., Mt Laurel, NJ) (AOAC, 2005; method 930.15).
Table 1: Composition of experimental diets (as-fed basis)

\begin{tabular}{llcc}
\hline & Carbadox $\left(\mathrm{mg} \mathrm{kg}^{-1}\right)$ & \\
& - & 27.5 & 55.0 \\
\hline Ingredient (\%) & 0 & 60.25 & 60.25 \\
\hline Ground corn & 60.25 & 32.00 & 32.00 \\
Soybean meal, $48 \%$ & 32.00 & 3.00 & 3.00 \\
Soybean oil & 3.00 & 0.50 & - \\
Cornstarch & 1.00 & 0.50 & 1.00 \\
Carbadox premix & - & 1.15 & 1.15 \\
Ground limestone & 1.15 & 1.40 & 1.40 \\
Monocalcium phosphate & 1.40 & 0.50 & 0.50 \\
Chromic oxide & 0.50 & 0.40 & 0.40 \\
Salt & 0.40 & 0.30 & 0.30 \\
Vitamin-mineral premix & ${ }^{\mathrm{b}}$ & 0.30 &
\end{tabular}

a: Carbadox premix (Mecadox, Phibro Animal Health, Ridgefield Park, NJ) contained $5.5 \mathrm{~g} \mathrm{~kg}^{-1}$ of carbadox; ': Supplied per kg of complete diet: vitamin A, 11,128 IU; vitamin $\mathrm{D}_{3}, 2,204$ IU; vitamin E, $66 \mathrm{IU}$; vitamin $\mathrm{K}, 1.42 \mathrm{mg}$; thiamin, $0.24 \mathrm{mg}$; riboflavin, $6.58 \mathrm{mg}$; pyridoxine, $0.24 \mathrm{mg}$; vitamin $\mathrm{B}_{12}, 0.03 \mathrm{mg}$; D-pantothenic acid, 23.5 $\mathrm{mg}$; niacin, $44 \mathrm{mg}$; folic acid, $1.58 \mathrm{mg}$; biotin, $0.44 \mathrm{mg}$; $\mathrm{Cu}, 10 \mathrm{mg}$ as copper sulfate; Fe, $125 \mathrm{mg}$ as iron sulfate; I, $1.26 \mathrm{mg}$ as potassium iodate; $\mathrm{Mn}, 60 \mathrm{mg}$ as manganese sulfate; Se, $0.3 \mathrm{mg}$ as sodium selenite and $\mathrm{Zn}, 100 \mathrm{mg}$ as zinc oxide

Table 2: Energy and nutrient composition of experimental diets (asfed basis)

\begin{tabular}{|c|c|c|c|}
\hline & \multicolumn{3}{|c|}{ Carbadox $\left(\mathrm{mg} \mathrm{kg}^{-1}\right)$} \\
\hline & 0 & 27.5 & 55.0 \\
\hline Metabolizable energy $\left(\mathrm{kcal} \mathrm{kg}^{-1}\right)^{\mathrm{a}}$ & 3.434 & 3.434 & 3.434 \\
\hline Crude protein $(\%)$ & 19.850 & 21.970 & 20.590 \\
\hline Calcium $(\%)^{\mathrm{a}}$ & 0.800 & 0.800 & 0.800 \\
\hline Phosphorus $(\%)^{\mathrm{a}}$ & 0.690 & 0.690 & 0.690 \\
\hline Available phosphorus $(\%)^{\mathrm{a}}$ & 0.320 & 0.320 & 0.320 \\
\hline \multicolumn{4}{|l|}{ Indispensable amino acid (\%) } \\
\hline Arg & 1.310 & 1.440 & 1.430 \\
\hline His & 0.570 & 0.590 & 0.620 \\
\hline Ile & 0.900 & 0.990 & 0.970 \\
\hline Leu & 1.840 & 1.970 & 1.920 \\
\hline Lys & 1.120 & 1.220 & 1.230 \\
\hline Met & 0.300 & 0.330 & 0.330 \\
\hline Phe & 1.010 & 1.100 & 1.070 \\
\hline Thr & 0.730 & 0.780 & 0.770 \\
\hline Trp & 0.210 & 0.220 & 0.210 \\
\hline Val & 1.010 & 1.100 & 1.090 \\
\hline \multicolumn{4}{|l|}{ Dispensable amino acid (\%) } \\
\hline Ala & 1.040 & 1.110 & 1.100 \\
\hline Asp & 2.020 & 2.200 & 2.180 \\
\hline Cys & 0.300 & 0.330 & 0.340 \\
\hline Glu & 3.720 & 3.990 & 3.910 \\
\hline Gly & 0.810 & 0.890 & 0.920 \\
\hline Pro & 1.120 & 1.210 & 1.230 \\
\hline Ser & 0.820 & 0.860 & 0.860 \\
\hline Tyr & 0.610 & 0.680 & 0.660 \\
\hline
\end{tabular}

Amino acids were analyzed on a Hitachi Amino Acid Analyzer, Model No. L8800 (Hitachi High Technologies America, Inc; Pleasaton, CA) using ninhydrin for postcolumn derivatization and norleucine as the internal standard (AOAC, 2005; method 982.30E). Prior to analysis, samples were hydrolyzed 
with $6 \mathrm{~N} \mathrm{HCl}$ for $24 \mathrm{~h}$ at $110^{\circ} \mathrm{C}$. Methionine and Cys were determined as Met sulfone and cysteic acid after cold performic acid oxidation overnight before hydrolysis. Tryptophan was determined after $\mathrm{NaOH}$ hydrolysis for $22 \mathrm{~h}$ at $110^{\circ} \mathrm{C}$. The $\mathrm{Cr}$ concentration in diets and ileal digesta samples was measured using an ICP method after nitric acid-perchloric acid wet ash sample preparation (AOAC, 2005; methods 990.08 and 968.088D).

Digestibility calculations: The AID of $\mathrm{CP}$ and AA in samples obtained from pigs fed the experimental diets were calculated using the following equation (Stein et al., 2007):

$\mathrm{AID}_{\mathrm{AA}}, \%=\left[1-\left(\mathrm{AA}_{\text {digesta }} / \mathrm{AA}_{\text {feed }}\right) \times\left(\mathrm{Cr}_{\text {feed }} / \mathrm{Cr}_{\text {digesta }}\right)\right] \times 100$

Where:

$\mathrm{AID}_{\mathrm{AA}}=$ The AID $(\%)$ of an AA

$\mathrm{AA}_{\text {digesta }}=$ The concentration of that $\mathrm{AA}$ in the ileal digesta

$\mathrm{AA}_{\text {feed }}=$ The $\mathrm{AA}$ concentration of that $\mathrm{AA}$ in the feed

$\mathrm{Cr}_{\text {feed }}=$ The $\mathrm{Cr}$ concentration in the feed

$\mathrm{Cr}_{\text {digesta }}=$ The $\mathrm{Cr}$ concentration in the ileal digesta

The AID for CP was also calculated using this equation.

Statistical analysis: Data were analyzed using the Generalized Linear Model procedures of SAS (SAS Institute Inc., Cary, NC). The model included period as the independent variable and AID values as response variables. For the analysis of pooled data during period 2-4, supplemental carbadox concentration was used as an independent variable. Contrasts were used to determine the effects of dietary treatments. The animal was the experimental unit. The alpha level used for determination of significance among means was 0.05 .

\section{RESULTS}

Animals remained healthy throughout the experiment and easily consumed their diets. In pigs fed the basal diet throughout the experiment (Table 3), the AID of CP, Ile, Leu, Lys, Met, Phe, Thr, Trp, Val, Ala, Cys, Glu and Tyr was greater $(\mathrm{p}<0.05)$ during period 24 than in period 1 and a tendency $(p<0.10)$ for an increase in the AID of His was also observed.

For pigs fed diets supplemented with $27.5 \mathrm{mg} \mathrm{kg}^{-1}$ of carbadox during period 2-4 and the basal diet during period 1, 5 and 6, the AID of His, Ile, Leu, Lys, Met, Phe, Val, Ala, Cys and Tyr increased by 4.2-7.6\% units during week 2, 3, 4 compared with period 1 ( $\mathrm{p}<0.05$; Table 4). A tendency $(\mathrm{p}<0.10)$ for an increase in the AID of Thr from period 1 to period 2-4 was also observed. The AID of Ile, Met, Ala and Pro decreased by 3.0-6.8 percentage units in period 5 and 6 compared with period $2-4(\mathrm{p}<0.05)$. When pigs were fed the diet containing $55.0 \mathrm{mg} \mathrm{kg}^{-1}$ of carbadox in period 2-4, the AID of CP and all AA except Arg, Pro and Ser was greater in period 2-4 compared with period $1(\mathrm{p}<0.05$; Table 5).

Table 3: Effect of feeding period on apparent ileal digestibility (\%) of crude protein and amino acids in pigs fed the basal diet

\begin{tabular}{|c|c|c|c|c|c|c|c|c|c|}
\hline & \multirow{2}{*}{\multicolumn{3}{|c|}{ Period }} & & & & \multirow[b]{3}{*}{ SEM } & \multicolumn{2}{|l|}{ p-values } \\
\hline & & & & & & & & \multirow{2}{*}{$\begin{array}{l}\text { Week } 1 \text { Vs } \\
\text { week 2-4 }\end{array}$} & \multirow{2}{*}{$\begin{array}{l}\text { Week 2-4 Vs } \\
\text { week } 5,6\end{array}$} \\
\hline & 1 & 2 & 3 & 4 & 5 & 6 & & & \\
\hline Crude protein & 72.0 & 77.5 & 75.4 & 79.9 & 76.5 & 77.6 & 1.59 & 0.006 & 0.721 \\
\hline \multicolumn{10}{|c|}{ Indispensable amino acid } \\
\hline Arg & 90.6 & 90.8 & 88.6 & 90.7 & 90.9 & 90.5 & 0.63 & 0.449 & 0.246 \\
\hline His & 79.9 & 82.8 & 80.7 & 85.9 & 85.2 & 84.9 & 1.39 & 0.054 & 0.149 \\
\hline Ile & 78.2 & 81.8 & 80.0 & 83.7 & 81.5 & 80.1 & 1.24 & 0.017 & 0.370 \\
\hline Leu & 80.3 & 83.5 & 81.4 & 84.9 & 83.4 & 82.3 & 1.12 & 0.034 & 0.691 \\
\hline Lys & 76.2 & 82.4 & 80.2 & 83.2 & 86.2 & 80.3 & 1.95 & 0.018 & 0.475 \\
\hline Met & 83.6 & 86.7 & 85.2 & 88.2 & 86.2 & 84.7 & 1.07 & 0.021 & 0.210 \\
\hline Phe & 79.4 & 82.7 & 80.6 & 84.4 & 82.3 & 82.2 & 1.19 & 0.033 & 0.796 \\
\hline Thr & 69.8 & 74.2 & 71.4 & 77.3 & 74.3 & 73.3 & 1.77 & 0.037 & 0.768 \\
\hline Trp & 79.1 & 83.1 & 81.2 & 85.4 & 81.5 & 84.3 & 1.16 & 0.005 & 0.755 \\
\hline Val & 74.5 & 78.5 & 76.6 & 80.7 & 79.4 & 77.2 & 1.42 & 0.021 & 0.822 \\
\hline Mean & 79.2 & 82.6 & 80.6 & 84.4 & 83.1 & 82.0 & 1.17 & 0.019 & 0.983 \\
\hline \multicolumn{10}{|l|}{ Dispensable amino acid } \\
\hline Ala & 72.1 & 77.9 & 74.9 & 80.2 & 77.2 & 75.3 & 1.67 & 0.008 & 0.348 \\
\hline Asp & 76.7 & 77.9 & 75.7 & 80.7 & 79.1 & 77.8 & 1.70 & 0.468 & 0.845 \\
\hline Cys & 65.3 & 74.8 & 71.2 & 77.9 & 72.9 & 74.5 & 3.15 & 0.017 & 0.759 \\
\hline Glu & 76.8 & 82.3 & 79.7 & 85.1 & 83.9 & 83.4 & 2.12 & 0.032 & 0.508 \\
\hline Gly & 55.8 & 61.0 & 58.6 & 69.8 & 66.9 & 63.7 & 3.74 & 0.105 & 0.525 \\
\hline Pro & 55.7 & 65.8 & 61.5 & 68.6 & 66.5 & 64.4 & 10.02 & 0.413 & 0.990 \\
\hline Ser & 79.3 & 81.1 & 78.4 & 83.7 & 80.8 & 81.3 & 1.71 & 0.366 & 0.998 \\
\hline Tyr & 78.5 & 82.5 & 80.7 & 85.2 & 81.6 & 82.3 & 1.14 & 0.003 & 0.411 \\
\hline Mean & 70.0 & 75.4 & 72.6 & 78.9 & 76.1 & 75.4 & 2.39 & 0.053 & 0.968 \\
\hline
\end{tabular}

Each least squares mean represents 5 observations 
American J. Animal \& Vet. Sci., 5 (3): 168-174, 2010

Table 4: Effect of feeding diets supplemented with $27.5 \mathrm{mg} \mathrm{kg}^{-1}$ of carbadox in period 2-4 on apparent ileal digestibility (\%) of crude protein and

\begin{tabular}{|c|c|c|c|c|c|c|c|c|c|}
\hline \multirow{3}{*}{ Carbadox $\left(\mathrm{mg} \mathrm{kg}^{-1}\right)$} & \multicolumn{6}{|c|}{ Period } & \multirow{3}{*}{ SEM } & \multirow{2}{*}{\multicolumn{2}{|c|}{ p-values }} \\
\hline & $\begin{array}{l}---- \\
1\end{array}$ & \multirow{2}{*}{2} & \multirow{2}{*}{3} & \multirow{2}{*}{4} & \multirow{2}{*}{5} & & & & \\
\hline & 0 & & & & & & & $\begin{array}{l}\text { Week } 1 \mathrm{Vs} \\
\text { week } 2,3,4\end{array}$ & $\begin{array}{l}\text { Week 2-4 Vs } \\
\text { week } 5,6\end{array}$ \\
\hline Crude protein & 72.3 & 74.8 & 76.6 & 78.1 & 72.5 & 75.4 & 1.86 & 0.064 & 0.149 \\
\hline \multicolumn{10}{|c|}{ Indispensable amino acid } \\
\hline Arg & 89.9 & 91.1 & 87.7 & 90.1 & 89.8 & 90.2 & 0.85 & 0.789 & 0.646 \\
\hline His & 76.6 & 79.9 & 80.9 & 82.5 & 81.7 & 81.9 & 1.66 & 0.031 & 0.644 \\
\hline Ile & 75.3 & 79.6 & 79.9 & 81.9 & 77.2 & 77.8 & 1.45 & 0.006 & 0.037 \\
\hline Leu & 76.7 & 80.2 & 80.6 & 82.4 & 79.2 & 79.6 & 1.39 & 0.013 & 0.203 \\
\hline Lys & 78.0 & 80.8 & 82.9 & 83.6 & 84.5 & 78.7 & 1.46 & 0.016 & 0.535 \\
\hline Met & 80.7 & 84.7 & 85.6 & 86.8 & 81.5 & 82.8 & 1.21 & 0.002 & 0.005 \\
\hline Phe & 76.6 & 80.1 & 80.1 & 82.3 & 78.2 & 79.5 & 1.40 & 0.017 & 0.138 \\
\hline Thr & 66.2 & 69.7 & 71.5 & 73.6 & 68.3 & 69.3 & 2.35 & 0.060 & 0.206 \\
\hline Trp & 78.4 & 80.4 & 80.2 & 82.1 & 75.7 & 81.5 & 1.41 & 0.133 & 0.090 \\
\hline Val & 71.1 & 75.7 & 76.8 & 78.2 & 75.7 & 74.0 & 1.78 & 0.011 & 0.224 \\
\hline Mean & 76.9 & 80.2 & 80.6 & 82.4 & 79.2 & 79.5 & 1.39 & 0.019 & 0.195 \\
\hline \multicolumn{10}{|c|}{ Dispensable amino acid } \\
\hline Ala & 70.4 & 74.9 & 77.4 & 78.4 & 72.4 & 72.8 & 2.08 & 0.015 & 0.038 \\
\hline Asp & 74.0 & 75.3 & 75.8 & 78.3 & 74.4 & 75.5 & 1.76 & 0.230 & 0.346 \\
\hline Cys & 63.8 & 68.4 & 72.6 & 73.3 & 65.8 & 72.3 & 3.05 & 0.043 & 0.397 \\
\hline Glu & 76.8 & 79.1 & 79.7 & 81.6 & 79.5 & 80.8 & 1.95 & 0.149 & 0.999 \\
\hline Gly & 56.3 & 60.5 & 66.2 & 67.6 & 63.1 & 61.4 & 3.63 & 0.060 & 0.456 \\
\hline Pro & 69.3 & 74.2 & 75.8 & 76.4 & 68.2 & 69.2 & 3.43 & 0.135 & 0.043 \\
\hline Ser & 76.0 & 76.4 & 76.1 & 77.4 & 76.1 & 78.4 & 1.94 & 0.785 & 0.719 \\
\hline Tyr & 76.8 & 79.9 & 80.5 & 82.6 & 77.4 & 79.4 & 1.52 & 0.028 & 0.079 \\
\hline Mean & 70.4 & 73.6 & 75.5 & 76.9 & 72.1 & 73.7 & 2.20 & 0.068 & 0.241 \\
\hline
\end{tabular}

Each least squares mean represents 5 observations

Table 5: Effect of feeding diets supplemented with $55.0 \mathrm{mg} \mathrm{kg}^{-1}$ of carbadox on the apparent ileal digestibility (\%) of crude protein and amino acids

\begin{tabular}{|c|c|c|c|c|c|c|c|c|c|}
\hline \multirow[b]{3}{*}{ Carbadox $\left(\mathrm{mg} \mathrm{kg}^{-1}\right)$} & \multicolumn{6}{|c|}{ Period } & \multirow[b]{3}{*}{ SEM } & \multirow{2}{*}{\multicolumn{2}{|c|}{$\mathrm{p}$-values }} \\
\hline & \multirow{2}{*}{1} & 2 & 3 & 4 & 5 & \multirow{2}{*}{6} & & & \\
\hline & & 55.0 & 55.0 & 55.0 & 0 & & & $\begin{array}{l}\text { Week } 1 \mathrm{Vs} \\
\text { week } 2,3,4\end{array}$ & $\begin{array}{l}\text { Week 2-4 Vs } \\
\text { wk } 5,6\end{array}$ \\
\hline Crude protein & 69.4 & 75.7 & 77.7 & 78.7 & 72.9 & 78.4 & 1.34 & 0.001 & 0.178 \\
\hline \multicolumn{10}{|c|}{ Indispensable amino acid } \\
\hline Arg & 90.2 & 90.9 & 88.3 & 90.4 & 89.6 & 88.9 & 0.62 & 0.704 & 0.278 \\
\hline His & 77.0 & 82.2 & 83.1 & 85.8 & 84.0 & 83.1 & 1.00 & 0.001 & 0.843 \\
\hline Ile & 74.2 & 81.6 & 82.2 & 82.7 & 78.4 & 80.2 & 1.19 & 0.001 & 0.015 \\
\hline Leu & 76.1 & 82.4 & 82.6 & 83.2 & 80.9 & 82.0 & 1.13 & 0.001 & 0.234 \\
\hline Lys & 76.2 & 83.7 & 84.4 & 85.1 & 86.5 & 79.9 & 1.19 & 0.001 & 0.268 \\
\hline Met & 79.8 & 86.5 & 87.6 & 87.5 & 80.5 & 85.0 & 1.76 & 0.001 & 0.010 \\
\hline Phe & 75.9 & 81.7 & 82.0 & 83.6 & 79.6 & 80.9 & 1.06 & 0.001 & 0.037 \\
\hline Thr & 64.8 & 72.5 & 72.6 & 74.8 & 69.4 & 71.9 & 1.31 & 0.001 & 0.036 \\
\hline Trp & 78.5 & 81.7 & 82.4 & 83.7 & 78.5 & 83.9 & 1.29 & 0.011 & 0.236 \\
\hline Val & 70.2 & 78.6 & 78.3 & 80.0 & 76.5 & 76.3 & 1.25 & 0.001 & 0.036 \\
\hline Mean & 76.3 & 82.2 & 82.4 & 83.7 & 80.4 & 81.2 & 0.96 & 0.001 & 0.037 \\
\hline \multicolumn{10}{|c|}{ Dispensable amino acid } \\
\hline Ala & 67.7 & 77.2 & 79.0 & 78.9 & 74.5 & 76.1 & 1.41 & 0.001 & 0.026 \\
\hline Asp & 72.4 & 76.7 & 78.1 & 79.9 & 76.3 & 76.8 & 1.33 & 0.001 & 0.179 \\
\hline Cys & 64.3 & 72.7 & 74.7 & 76.4 & 63.3 & 73.1 & 2.67 & 0.003 & 0.014 \\
\hline Glu & 77.3 & 80.4 & 84.1 & 85.4 & 83.2 & 83.8 & 1.51 & 0.002 & 0.916 \\
\hline Gly & 55.3 & 65.5 & 69.1 & 70.8 & 64.5 & 66.7 & 2.88 & 0.001 & 0.291 \\
\hline Pro & 55.7 & 71.0 & 70.5 & 72.8 & 62.9 & 70.1 & 9.03 & 0.143 & 0.552 \\
\hline Ser & 74.9 & 77.1 & 75.9 & 80.0 & 77.7 & 80.6 & 1.37 & 0.095 & 0.255 \\
\hline Tyr & 76.2 & 82.0 & 81.9 & 83.9 & 79.5 & 81.4 & 1.25 & 0.001 & 0.074 \\
\hline Mean & 68.0 & 75.3 & 76.7 & 78.5 & 72.7 & 76.1 & 1.73 & 0.001 & 0.135 \\
\hline
\end{tabular}


American J. Animal \& Vet. Sci., 5 (3): 168-174, 2010

Table 6: Effect of supplemental carbadox on apparent ileal CP and AA digestibility changes (percentage unit) from period 1 to period 2-4

\begin{tabular}{|c|c|c|c|c|c|c|}
\hline \multirow[b]{2}{*}{ Item } & \multicolumn{3}{|c|}{ Carbadox $\left(\mathrm{mg} \mathrm{kg}^{-1}\right)$} & \multirow[b]{2}{*}{ SEM } & \multicolumn{2}{|l|}{ p-values ${ }^{\mathrm{a}}$} \\
\hline & 0 & 27.5 & 55.0 & & 0 Vs 27.5 & 0 Vs 55.0 \\
\hline Crude protein & 5.55 & 4.24 & 7.98 & 1.59 & 0.572 & 0.269 \\
\hline \multicolumn{7}{|c|}{ Indispensable amino acid } \\
\hline Arg & -0.56 & -0.27 & -0.27 & 0.61 & 0.744 & 0.736 \\
\hline His & 3.25 & 4.49 & 6.70 & 1.34 & 0.522 & 0.066 \\
\hline Ile & 3.69 & 5.17 & 7.95 & 1.14 & 0.374 & 0.009 \\
\hline Leu & 2.90 & 4.40 & 6.61 & 1.09 & 0.346 & 0.017 \\
\hline Lys & 5.74 & 4.48 & 8.26 & 1.59 & 0.585 & 0.253 \\
\hline Met & 3.06 & 4.97 & 7.47 & 1.08 & 0.227 & 0.005 \\
\hline Phe & 3.12 & 4.25 & 6.48 & 1.05 & 0.463 & 0.024 \\
\hline Thr & 4.53 & 5.44 & 8.57 & 1.70 & 0.713 & 0.089 \\
\hline $\operatorname{Trp}$ & 4.16 & 2.56 & 4.12 & 1.09 & 0.315 & 0.979 \\
\hline Val & 4.06 & 5.78 & 8.72 & 1.32 & 0.373 & 0.013 \\
\hline Mean & 3.40 & 4.13 & 6.46 & 1.13 & 0.655 & 0.052 \\
\hline \multicolumn{7}{|c|}{ Dispensable amino acid } \\
\hline Ala & 5.54 & 6.46 & 10.65 & 1.63 & 0.700 & 0.027 \\
\hline Asp & 1.45 & 2.53 & 5.85 & 1.49 & 0.619 & 0.036 \\
\hline Cys & 9.34 & 7.68 & 10.33 & 3.11 & 0.712 & 0.815 \\
\hline Glu & 5.57 & 3.39 & 6.06 & 1.87 & 0.422 & 0.848 \\
\hline Gly & 7.27 & 8.42 & 13.18 & 2.74 & 0.773 & 0.121 \\
\hline Pro & 9.63 & 6.20 & 15.80 & 2.92 & 0.420 & 0.128 \\
\hline Ser & 1.82 & 0.62 & 2.76 & 1.59 & 0.605 & 0.666 \\
\hline Tyr & 4.31 & 4.21 & 6.36 & 1.21 & 0.956 & 0.221 \\
\hline Mean & 5.62 & 4.94 & 8.87 & 1.79 & 0.794 & 0.188 \\
\hline
\end{tabular}

Each least squares mean represents 15 observations (5 pigs for 3 periods); ${ }^{\mathrm{a}}: \mathrm{p}$-values are from single degree of freedom contrasts

A tendency $(\mathrm{p}<0.10)$ for a greater AID of Ser in period 2-4 compared with period 1 was also observed. The AID of Ile, Met, Phe, Thr, Val, Ala and Cys decreased by 2.2-6.4 percentage units during period 5 and 6 when no carbadox was fed compared with period 2-4 $(\mathrm{p}<0.05)$.

To remove the effect of period, AID values were standardized by calculating the changes in digestibility from period 1 to period 2-4 (Table 6). The changes in AID from period 1 to period 2-4 for Ile, Leu, Met, Phe, $\mathrm{Val}$, Ala and Asp were greater in pigs fed diets supplemented with $55.0 \mathrm{mg} \mathrm{kg}$-1 of carbadox than in pigs fed the basal diet $(\mathrm{p}<0.05)$. There was also a tendency $(p<0.10)$ for a greater increase in the AID of His and Thr in pigs fed the diet containing $55.0 \mathrm{mg} \mathrm{kg}^{-1}$ of carbadox compared with pigs fed the basal diet. However, inclusion of $27.5 \mathrm{mg} \mathrm{kg}^{-1}$ of carbadox in the diets did not result in significantly greater increases in the AID of AA from period 1 to period 2-4, than if the basal diet was fed.

The AID of Ile, Met, Ala and Pro decreased during period 5 and 6 compared with period 2-4 in pigs fed diets supplemented with $27.5 \mathrm{mg} \mathrm{kg} \mathrm{kg}^{-1}$ carbadox ( $\mathrm{p}<0.05$; Table 4) and the AID of Ile, Met, Phe, Thr, Val, Ala and Cys decreased during period 5 and 6 compared with period 2-4 in pigs fed diets supplemented with $55.0 \mathrm{mg} \mathrm{kg}^{-1}$ carbadox $(\mathrm{p}<0.05$; Table 5).

\section{DISCUSSION}

The greater digestibility of $\mathrm{CP}$ and most AA during period 2-4 compared with period 1 (Table 3) indicates that $\mathrm{CP}$ and AA digestibility increases during the postweaning period, which may be caused by increased enzyme secretion or maturation of the gastrointestinal tract. The activities of digestive enzymes including lipase, trypsin, chymotrypsin and amylase increase by 2 fold from 28-56 day of age (Jensen et al., 1997). All AA in the diets used in this experiment were provided in the form of proteins and no crystalline AA were used. Thus, the digestive enzyme activities may have limited protein digestion during the first period of the experiment. Older pigs have a more mature gastrointestinal tract, which allows them to better digest dietary cereals and absorb more nutrients (Graham et al., 1986). An increase in the AID of AA as weanling pigs became older has been previously reported (Diebold et al., 2004). However, results of this experiment indicate that it was only during the initial few weeks of the experiment that protein digestion was limited because the AID of AA was not increased from period 2-4 to period 5 and 6 . It therefore, appears that enzyme secretion in period 2-4 was sufficient to maximize protein digestion and a further increase was not attained in period 5 and 6 .

In the present experiment, all pigs have an increase in the digestibility of protein and absorption of AA during the post-weaning period, but pigs fed diets 
containing $55.0 \mathrm{mg} \mathrm{kg}^{-1}$ of carbadox have a greater increase in digestibility of AA than pigs fed diets containing no carbadox. Pigs fed diets containing $27.5 \mathrm{mg} \mathrm{kg}^{-1}$ of carbadox have increases in the AID of AA that are intermediate between the values obtained for pigs fed diets containing no carbadox and pigs fed diets containing $55.0 \mathrm{mg} \mathrm{kg}^{-1}$ of carbadox. We are not aware of any other data that have documented these effects when carbadox is fed to weanling pigs, but it has been shown that carbadox increases CP digestion and retention in growing pigs (Yen et al., 1976). In growing-finishing barrows $(39-83 \mathrm{~kg})$ fed a high-fiber diet also had increased AID of several AA if carbadox was included in the diet (Partanen et al., 2001).

The improved CP utilization in pigs fed carbadox containing diets is associated with a Lys sparing effect of carbadox (Yen and Veum, 1982). In addition to the increased AID of Lys in pigs fed carbadox, a reduced weight of the small intestine (Yen et al., 1985) and/or a decreased ammonia production in the gastrointestinal tract may also contribute to the Lys sparing effect of carbadox (Yen and Pond, 1990).

The elevated AID of AA in pigs fed diets containing $55.0 \mathrm{mg} \mathrm{kg}^{-1}$ carbadox will result in less protein entering the hindgut. Protein in the hindgut of weanling pigs may result in increased susceptibility to diarrhea (Houdijk et al., 2007; Heo et al., 2008; Yue and Qiao, 2008). Inclusion of carbadox in diets fed to weanling pigs may, therefore, reduce the incidence of diarrhea during the post-weaning period.

The AID of AA was not increased from period 2-4 to period 5 and 6 in pig. It therefore, appears that enzyme secretion in period 2-4 was sufficient to maximize protein digestion and a further increase was not attained in period 5 and 6 .

The AID of Ile, Met, Ala and Pro decreased during period 5 and 6 compared with period 2-4 in pigs fed diets supplemented with $27.5 \mathrm{mg} \mathrm{kg} \mathrm{kg}^{-1}$ carbadox ( $\mathrm{p}<0.05$; Table 4) and the AID of Ile, Met, Phe, Thr, Val, Ala and Cys decreased during period 5 and 6 compared with period 2-4 in pigs fed diets supplemented with $55.0 \mathrm{mg} \mathrm{kg}^{-1}$ carbadox $(\mathrm{p}<0.05$; Table 5).

The AID of many AA decreased during period 5 and 6 when supplemental carbadox was removed from the diet compared with period 2-4. These observations indicate that the increased AID that is caused by carbadox is observed only as long as carbadox is included in the diet and the effect of carbadox disappears as soon as carbadox is removed from the diet. There is, thus, no carryover effect.

\section{CONCLUSION}

The inclusion of carbadox at $55.0 \mathrm{mg} \mathrm{kg}^{-1}$ in diets fed to weanling pigs increases the AID of many AA, but this effect disappears within one wk if carbadox is removed from the diet.

\section{REFERENCES}

AOAC., 2005. Official Methods of Analysis. 18th Edn., Association of Official Analytical Chemists, Gaithersburg, MD., ISBN: 0-935584-77-3, pp: 1920.

Cromwell, G.L., 2000. Antimicrobial and Promicrobial Agents. In: Swine Nutrition, Lewis, A.J. and L.L. Southern (Eds.). CRC Press, Boca Raton, Florida, ISBN: 13: 978-0849306969, pp: 421-426.

Diebold, G., R. Mosenthin, H.P. Piepho and W.C. Sauer, 2004. Effect of supplementation of xylanase and phospholipase to a wheat-based diet for weanling pigs on nutrient digestibility and concentrations of microbial metabolites in ileal digesta and feces. J. Anim. Sci., 82: 2647-2656. PMID: 15446482

Graham, H., K. Hesselman, E. Jonsson and P. Aman, 1986. Influence of beta-glucanase supplementation on digestion of a barley-based diet in the pig gastrointestinal tract. Nutr. Rep. Int., 34: 1089-1096. http://apps.isiknowledge.com

Heo, J.M., J.C. Kim, C.F. Hansen, B.P. Mullan, D.J. Hampson and J.R. Pluske, 2008. Effects of feeding low protein diets to piglets on plasma urea nitrogen, faecal ammonia nitrogen, the incidence of diarrhea and performance after weaning. Arch. Anim. Nutr., 62: 343-358. PMID: 18942582

Houdijk, J.G.M., F.M. Campbell, P.D. Fortomaris, P.D. Eckersall and I. Kyriazakis, 2007. Effects of sub-clinical post-weaning colibacillosis and dietary protein on acute phase proteins in weaner pigs. Livest. Sci., 108: 182-185. DOI: 10.1016/j.livsci.2007.01.048

Jensen, M.S., S.K. Jensen and K. Jakobsen, 1997. Development of digestive enzymes in pigs with emphasis on lipolytic activity in the stomach and pancreas. J. Anim. Sci., 75: 437-445. PMID: 9051467

NRC., 1998. Nutrient Requirements of Swine. 10th Edn., National Academy Press, Washington DC., USA., ISBN: 0-309-05993-3, pp: 210.

Partanen, K., T. Jalava, J. Valaja, S. Perttila and H. Siljander-Rasi et al., 2001. Effect of dietary carbadox or formic acid and fiber level on ileal and faecal nutrient digestibility and microbial metabolite concentrations in ileal digesta of the pig. Anim. Feed Sci. Technol., 93: 137-155. DOI: 10.1016/S0377-8401(01)00288-7 
Stein, H.H., C.F. Shipley and R.A. Easter, 1998. Technical note: A technique for inserting a Tcannula into the distal ileum of pregnant sows. J. Anim. Sci., 76: 1433-1436. PMID: 9621950

Stein, H.H., B. Seve, M.F. Fuller, P.J. Moughan and C.F.M. de Lange, 2007. Invited review: Amino acid bioavailability and digestibility in pig feed ingredients: Terminology and application. J. Anim. Sci., 85: 172-180. PMID: 17179553

Thrasher, G.W., J.E. Shively, C.E. Askelson, W.E. Babcock and R.R. Chalquest, 1969. Effect of feeding carbadox upon the growth and performance of young pigs. J. Anim. Sci., 28: 208-215. PMID: 5773530

Yen, J.T. and T.L. Veum, 1982. Effect of lysine, tryptophan and (or) carbadox additions to low protein corn-soybean meal diets for young pigs. J. Anim. Sci., 55: 1099-1108. PMID: 6816782

Yen, J.T. and W.G. Pond, 1990. Effect of carbadox on net absorption of ammonia and glucose into hepatic portal vein of growing pigs. J. Anim. Sci., 68: 4235-4242. PMID: 2286564
Yen, J.T., A.H. Jensen, N.H. Bajjalieh and V.D. Ladwig, 1976. Effect of methyl-3-(2quinoxalinylmethylene) carbazate-N1, N4-dioxide on nitrogen and energy digestibility in and performance of young pigs. J. Anim. Sci., 42: 375-380. http://jas.fass.org/cgi/content/abstract/42/2/375

Yen, J.T., J.A. Nienaber, W.G. Pond and V.H. Varel, 1985. Effect of carbadox on growth, fasting metabolism, thyroid function and gastrointestinal tract in young pigs. J. Nutr., 115: 970-979. PMID: 3926967

Yue, L.Y. and S.Y. Qiao, 2008. Effects of low-protein diets supplemented with crystalline amino acids performance and intestinal development in piglets over the first 2 weeks after weaning. Livest. Sci., 115: 144-152. DOI: 10.1016/j.livsci.2007.06.018 